In textile engineering good progress is reported in the analytical study of loom noise and in a study of the drying of textiles. In textile technology, work on the chemistry and practice of finishing fabrics made from both wool and man-made fibres continued and on the measurement of yarn irregularity. The chemical properties of pigmented wool, the action of concentrated sulphuric acid on wool, the removal of compounds of high molecular weight from textile materials and the degradation and yellowing of nylon were also studied.

In the Department of Colour Chemistry and Dyeing the course of the changes which occur in the reaction of aromatic carbonyl compounds with basic substances was examined, a study of stilbenequinone and its derivatives was completed, and work on elimination of groups from vat dyes on reduction and on the reactions of sulphinic acids with azo compounds and azines continued. A group of diazonium salts soluble in benzene was prepared, and a study of the interaction of aminoanthroquinones and aminofluorenanes with nitrobenzene and $\alpha$-nitronaphthalene was completed, as well as work on the vapour pressure and absorption energies of some anthroquinone and azo dyes. The influence of the acetyl value of acetate rayon on the rate of dyeing and affinity for disperse dyes is being studied.

\section{Journal of Nutrition}

Dr. Richard H. Barnes, dean of the Cornell University Graduate School of Nutrition, Ithaca, New York, has been appointed editor of the Journal of Nutrition. He succeeds Dr. George R. Cowgill of the Yale Nutrition Laboratory, who has served as editor for twenty years. Dr. Cyril L. Comar, director of the Laboratory of Radiation Biology, New York State Veterinary College, has been appointed associate editor. The appointments became effective July 1, 1959. The editorial offices of the Journal of Nutrition are being moved from Yale University to the Cornell University campus. Manuscripts should be sent to Dr. Barnes at the Graduate School of Nutrition, Savage Hall, Cornell University, Ithaca, New York.

\section{Nature Conservancy Awards for 1959}

THe Nature Conservancy announces the following awards of research studentships for postgraduate training in ecology, tenable for periods up to three years at the universities shown: Botany: J. K. Marshall (Cambridge), D. P. Nicholas (Liverpool), W. J. Roff (Cambridge), J. T. R. Sharrock (Southampton), D. T. Streeter (London); Zoology: M. L. Clark (Leeds), E. R. Creed (Oxford), J. M. Edington (Durham), C. J. Henty (Oxford), J. B. Nelson (Oxford), G. C. Phillips (Oxford); Geography: I. G. Simmons (London).

\section{University News :}

Edinburgh

Prof. A. D. Ritchie, professor of logic and meta. physics in the University of Edinburgh, retires on September 30; his long and distinguished career was mentioned in reviewing his recent book, "Studies in the History and Methods of the Sciences" (Nature, July 4, p. 4). Prof. E. E. Harris, formerly professor of philosophy in the University of the Witwatersrand, has been appointed acting head of Prof. Ritchie's Department for one year.

Swansea

THE following appointments have been made in the University College of Swansea for the session 1959
60 ; Dr. J. R. Cross, superintendent of the Chemistry Laboratories; Miss Glenys Thomas, map curator and cartographer in the Department of Geography; Mr. P. W. Davies, assistant lecturer in metallurgy ; Dr. H. E. Evans, lecturer in engineering; Mr. B. W. Preece, assistant lecturer in engineering.

\section{Announcements}

Mr. Walter Garner, formerly chairman of the Yorkshire Section and at present chairman of the London and District Section of the Textile Institute, and Dr. A. R. Urquhart, honorary secretary of the Institute and an assistant director of the British Cotton Industry Research Association, have been awarded the Service Medal of the Textile Institute.

Prof. H. MARK, director of the Polymer Research Institute of the Polytechnic Institute of Brooklyn, New York, will deliver the Fourth Baekeland Memorial Lecture under the title "Recent Progress in Polymer Chemistry". The Lecture will be delivered on October 22 at the Royal Institution, Albemarle Street, London, W.1.

The International Commission on Zoological Nomenclature has been given accommodation in the British Museum (Natural History). This will greatly facilitate the work of the Commission by reason of the unique library facilities and wide range of specialist advice available. Correspondence should in future be addressed to Mr. N. D. Riley (Honorary Secretary), International Commission on Zoological Nomenclature, c/o British Museum (Natural History), London, S.W.7.

THE second session (1959-60) of the Welsh Soils Discussion Group will open with a meeting in the Department of Agricultural Chemistry, University College, Bangor, on October 28. The subject for discussion will be "Mineralogical Aspects of Soil Science"; the introductory speakers will be Dr. F. Smithson and Mr. R. I. Davies (Bangor) and Mr. D. F. Ball (Nature Conservancy, Bangor). Further information can be obtained from Mr. J. A. Taylor, Geography Department, University College, Aberystwyth.

The Scottish Conference on "Relationships in Industry : Some Changing Concepts of Management", which is being organized jointly by the British Institute of Management and the Ministry of Labour, will be held at Gleneagles Hotel during October 23-24. It will be opened by Sir Alexander Fleck, chairman of Imperial Chemical Industries, Ltd. Further information can be obtained from the British Institute of Management, Management House, 80 Fetter Lane, London, E.C.4.

In November 1859 Charles Darwin published "The Origin of Species" and Queen Victoria granted the Royal Title to the Royal Society of Victoria. To mark these two centenaries, the Society is organizing a symposium on the Evolution of Living Species, to be held in Melbourne during December 7-11. Dr. Ernest Mayr of the United States will be the guest speaker. Further information can be obtained from the Honorary Secretary, Royal Society of Victoria, 9 Victoria Street, Melbourne, C.1, Victoria.

REFERRING to the review in Nature of June 27, p. 1766, Messrs. Chapman and Hall state that the present American price of Cox's "Planning of Experiments" is 7.50 dollars. 